\title{
Design, Analysis and Selection of Electric and Magnetic loading for Different Rating of Squirrel Cage Induction Motors by using MATLAB GUI Software
}

\author{
Dimple Sharma $^{1}$, R.K. Saini ${ }^{2}$, Sunil Pathania ${ }^{3}$ \\ M.Tech Student, Shoolini University, Solan (H.P), India ${ }^{1}$ \\ Assistant Professor, Shoolini University, Solan (H.P), India ${ }^{2,3}$
}

\begin{abstract}
This paper presents the designing of the main dimensions and the selection of the magnetic and electric loading for different rating of squirrel cage induction motors to reduce the overall losses and to improve the power factor. A software development strategy for the design of main dimensions and the effects of various factors are studies to select the best parameters for the particular ratings of the machines. The redesign time can be reduced with the help of this software during the course of learning and manufacturing of the inductions motors. The idea of designing the main dimensions of three phase squirrel cage induction motor by MAT LAB GUI is simple fast and friendly nature.
\end{abstract}

Index Terms: Three phase squirrel cage induction motor, MAT LAB- GUI.

\section{INTRODUCTION}

Three phase induction motor is an important class of electric motors which finds wide application in industry and farms sector. More than $85 \%$ of industrial motors in use today are in fact induction motors. Although the design procedure for induction motor are well established, but there are some areas which require special attention [1] . After the completion of calculations of induction motor design, it has been observed that performance of the machine is not satisfactory .In this condition the designer has to change some design parameters like electric and magnetic loading. Hence iterative calculations of the entire design procedure are required to achieve the satisfactory and economic design. After designing the main parts of the machine the suitable electric and magnetic loading must be selected for proper selection of number turns per phase for the stator winding, stator conductor per slot, end ring current, copper loss, slot leakage reactance etc for stator and rotor design. This type of software will be a beneficial tool for the educational purpose also [2-4] The basic objective of this paper is to modify the design procedure for different rating of squirrel cage induction motors retaining the main dimensions, to get the desired performance under the variation of electric and magnetic loading [3-5].

\subsection{Role of Electric and magnetic loading.}

A small magnetic loading gives good power factor and reduces the core losses but a small over load capacity. A high value of magnetic loading gives poor power factor and increases the core losses also. For general purpose, over load capacity and for large capacity high speed rang should be 0.3 to0.55Tesla, 0.6 to 0.65 Tesla and 0.45 to 0.55 Tesla respectively. On the other hand the high value of electric loading is restricted because of temperature rise and over Load capacity .Depending on the capacity of the machine the value of electric loading varies between 5000 to 45000amp.cond/m. [1, 3]

\subsection{OUT PUT EQUATIONS.}

The following Equations are used for the calculations of the main dimensions of the machine and the same equations are used to develop the MAT LAB GUI software for the inputs and outputs. Let

Es=EMF induced per phase in volts

(Induced EMF per phase=Applied voltage per phase).

Iph=Current per phase.

Ts $=$ Number of turns per phase.

$\Phi=$ Flux per pole in the air gap.

$\mathrm{P}=$ Number of poles.

$\mathrm{Kw}=$ Winding Factor.

$\mathrm{B}_{\mathrm{av}}=$ Value of flux density in the air gap.

ac=Ampere conductors per meter of the armature periphery.

$\mathrm{D}=$ Length of stator bore diameter in meters.

$\mathrm{L}=$ Length of stator core in meters.

$\mathrm{Ns}=$ Synchronous speed of the motor in r.p.s.

$\eta=$ Full load efficiency.

$\operatorname{Cos} \Phi=$ Full load power factor.

$=$ Pole pitch $=\pi^{*} \mathrm{D} / \mathrm{P}$.

1.3 Calculations for the main dimensions of stator and Rotor.

If the rating of the machine is given in horse power, then

K.V.A =H.P* 0.746/ $\eta * \operatorname{Cos} \varnothing$

If the rating of the Machine is given in $\mathrm{KW}$, then

$\mathrm{KVA}=\mathrm{KW} / \eta * \operatorname{Cos} \varnothing$

Synchronous speed of the machine $\left(\mathrm{n}_{\mathrm{s}}\right)=$ Speed in r.p.m/f

Number of poles $(p)=120 * f /$ Speed in r.p.m.

The product of $\mathrm{D}^{2} \mathrm{~L}=\mathrm{KVA} / \mathrm{C}_{0 *} \mathrm{n}_{\mathrm{s}}$.

Where $\mathrm{C}_{0}=1.11 * \pi^{2} * \mathrm{~K}_{\mathrm{w}} * \mathrm{~B}_{\mathrm{av}} * \mathrm{ac}^{*} * 10^{-3}$

Choose L/ $\square \square \square$ to 1.5

Peripheral Velocity $(\mathrm{V})=\pi \mathrm{Dn} \mathrm{m} / \mathrm{sec}$.

(If the value of peripheral velocity is less than $30 \mathrm{~m} / \mathrm{sec}$ then no radial vent. Duct is required. 
Net iron length will be $=0.9$ L (Assume stacking Magnetic loading $=0.45$ factor $=0.9$ )

Flux per pole $\left(\Phi_{\mathrm{m}}\right)=\mathrm{B}_{\mathrm{av} *} \pi * \mathrm{D} * \mathrm{~L} / \mathrm{P}$

Stator turns per phase $\left(\mathrm{T}_{\mathrm{s}}\right)=\mathrm{Es} / 4.44 * \mathrm{KW}_{\mathrm{s}} * \mathrm{f} * \Phi_{\mathrm{m}}$

Stator current per phase $\left(\mathrm{I}_{\mathrm{s}}\right)=\mathrm{KVA}^{*} 1000 / 3 * \mathrm{E}_{\mathrm{s}}$

Assume current density $\left({ }_{\mathrm{s}}\right)=4$ to $5 \mathrm{~A} / \mathrm{mm}^{2}$

Conductor cross section $\left(\mathrm{A}_{\mathrm{s}}\right)=\mathrm{I}_{\mathrm{S}} / \delta_{\mathrm{s}} \mathrm{mm}^{2}$

Choose slots per pole per phase $(\mathrm{p})=3$

Total number of slots for stator $=3 * \mathrm{P} * \mathrm{P}_{\mathrm{h}}$

Resistance per phase $(\mathrm{Rs})=0.021 * \mathrm{Lmt} * \mathrm{Ts} / \mathrm{As}$ in ohms.

Total $\mathrm{I}^{2} \mathrm{R}$ losses $\quad=3 * \mathrm{Is}^{2} * \mathrm{Rs}^{*} 10^{-3}$ in $\mathrm{Kw}$

Maximum flux density in the air gap $(\mathrm{Bg})=\mathrm{Bav}^{*} \pi / 2$

No load Maximum flux per pole $(\mathrm{fp})=\mathrm{Bg} * \pi^{*} \mathrm{D} * \mathrm{~L}$

Length of air Gap $(\mathrm{Lg})=0.2+2(\mathrm{D} * \mathrm{~L})^{0.5}$

Rotor bar Current $\left(\mathrm{I}_{\mathrm{b}}\right)=$ m.m.f*6*Is*Ts

Area of each bar $\left(\mathrm{a}_{\mathrm{b}}\right)=\mathrm{Ib} / \delta_{\mathrm{s}}$

End ring Current $(\mathrm{Ie})=\mathrm{Sr} * \mathrm{Ib} / \pi * \mathrm{P}$

Area of End ring $(\mathrm{Ae})=\mathrm{Ie} / / \delta_{\mathrm{s}}$

Resistance of each bar $(\mathrm{Rb})=0.021 * 1 \mathrm{~b} / \mathrm{a}_{\mathrm{b}}$

Copper losses in all the bars $(\mathrm{A})=\mathrm{I}_{\mathrm{b}}{ }^{2} * \mathrm{Rb}^{*} \mathrm{Sr}$

Resistance of each end ring $(\mathrm{Re})=0.021 * \pi * \mathrm{Mr} / \mathrm{Ae}$

Total copper loss in both the rings $(\mathrm{B})=2 * \mathrm{Ie}^{2} * \mathrm{Re}$

Total copper losses $=\mathrm{A}+\mathrm{B}$ Watts $[\mathbf{1 , 3}]$.

\subsection{RESULTS}

The results of the Analytical method using the above equations are compared with the software MATLAB-GUI development

Table 1: Analytical Results Vs MATLAB GUI Results

\begin{tabular}{|l|l|l|}
\hline Induction motor parameters & $\begin{array}{c}\text { Analytical Results } \\
\text { (Output) }\end{array}$ & \multicolumn{1}{|c|}{$\begin{array}{c}\text { MATLAB GUI } \\
\text { Results } \\
\text { (Output) }\end{array}$} \\
\hline Output coefficient & 115.975 & 115.984 \\
Synchronous Sped. & 1000 & 1000 \\
Number of poles. & 6 & 6 \\
Product of D'L. & $0.033 \mathrm{~m}^{3}$ & $0.034 \mathrm{~m}^{3}$ \\
Diameter Of core. & $0.44 \mathrm{~m}$ & $0.45 \mathrm{~m}$ \\
Length of core. & $0.209 \mathrm{~m}$ & $0.209 \mathrm{~m}$ \\
Net Iron Length. & $0.171 \mathrm{~m}$ & $0.172 \mathrm{~m}$ \\
Flux/pole. & $0.020232 \mathrm{wb}$ & $0.020232 \mathrm{wb}$ \\
Stator turns/phase & 102 & 102 \\
Stator current/phase & $48.939 \mathrm{Amp}$ & 48.94 \\
Conductor per slot & 11 & 11 \\
No of stator slots. & 54 & 54 \\
Slot Pitch. & $0.023 \mathrm{~m}$ & $0.023 \mathrm{~m}$ \\
Resistance/Phase. & $0.1870 \mathrm{Ohm}$ & $0.187 \mathrm{ohm}$ \\
Total Copper losses. & $1346.97 \mathrm{~W}$ & $1346.94 \mathrm{~W}$ \\
Length of Air Gap. & $0.780 \mathrm{~mm}$ & $1.73 \mathrm{~mm}$ \\
Rotor bar current. & $456.93 \mathrm{Amp}$ & $456.92 \mathrm{amp}$ \\
Area of each bar. & $70.298 \mathrm{~mm}^{2}$ & $70.30 \mathrm{~mm} 2$ \\
End ring current. & $1381.75 \mathrm{amp}$ & $1380.43 \mathrm{Amp}$ \\
Area of End Ring. & $212.57 \mathrm{~mm}^{2}$ & $211.04 \mathrm{~mm}{ }^{2}$ \\
Resistance of Each end ring. & $0.00 \mathrm{ohms}$ \\
Total copper losses in both & $0.00 \mathrm{ohm}$ & $136.22 \mathrm{~W}$ \\
end rings. & $136.22 \mathrm{~W}$ & $1060.57 \mathrm{~W}$ \\
Total copper losses. & $1060.57 \mathrm{~W}$ & \\
\hline
\end{tabular}

as shown in Table No-1 for the rating of $50 \mathrm{Kw}$ and the effects of the variables parameters like electric, magnetic loading and voltage unbalance are observed on 5HP, 7HP and 9HP induction motors .Table number 2, 3 and 4 are used for the calculation of variable parameters and the effects of results are observed in graph number 1,2 and 3 .

\subsection{INPUT PARAMETERS}

Applied voltage $=400 \mathrm{~V}$

Rated frequency $=50 \mathrm{~Hz}$

Number of phases $=3$

Full load efficiency $=0.90$

Power factor $=0.87$

Electric loading $=21000$

Types of winding $=$ single layer

Winding factor $=0.955$

Type of Rotor windings =Cage type

Rotor winding factor $=1$

Power factor $=0.87$

Magnetic loading $=0.45$

Electric loading $=21000$

Types of winding $=$ single layer

Winding factor $=0.955$

Type of Rotor windings $=$ Cage type

Air gap flux density vs Stator turns per phase

\begin{tabular}{|c|c|c|c|c|c|c|c|}
\hline $\begin{array}{c}\text { Air gap Flux } \\
\text { Density }\end{array}$ & 0.3 & 0.34 & 0.37 & 0.45 & 0.51 & 0.57 & 0.63 \\
\hline 5HP & 632 & 606 & 590 & 552 & 530 & 510 & 494 \\
\hline $7 \mathrm{HP}$ & 505 & 485 & 471 & 441 & 423 & 408 & 394 \\
\hline $9 \mathrm{HP}$ & 427 & 410 & 398 & 373 & 358 & 345 & 333 \\
\hline
\end{tabular}

Table No -2

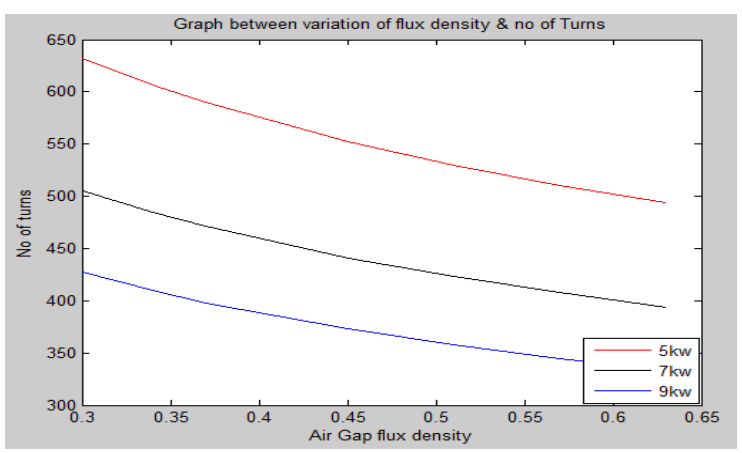

Graph No-1

Ampere Conductors Vs Stator turns per phase

\begin{tabular}{|c|c|c|c|c|c|c|c|}
\hline $\begin{array}{c}\text { Ampere } \\
\text { conductor }\end{array}$ & 6000 & 12000 & 18000 & 24000 & 30000 & 36000 & 42000 \\
\hline $5 \mathrm{HP}$ & 238 & 377 & 495 & 599 & 696 & 786 & 871 \\
\hline $7 \mathrm{HP}$ & 190 & 301 & 395 & 479 & 556 & 628 & 696 \\
\hline $9 \mathrm{HP}$ & 160 & 255 & 334 & 405 & 470 & 531 & 588 \\
\hline
\end{tabular}

Table No -3

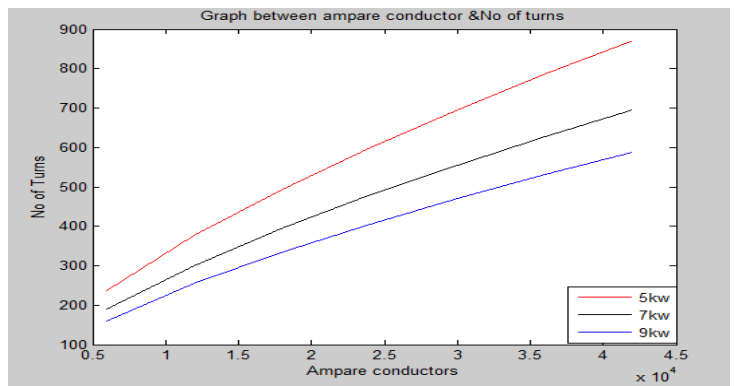

Graph No -2

Variation of Voltage Vs Stator copper losses in KW

\begin{tabular}{|c|c|c|c|c|c|c|c|}
\hline $\begin{array}{c}\text { Voltages/ } \\
\text { Rating of } \\
\text { Machine }\end{array}$ & 400 & 395 & 390 & 385 & 380 & 375 & 370 \\
\hline $5 \mathrm{HP}$ & 0.164 & 0.166 & 0.168 & 0.171 & 0.173 & 0.175 & 0.178 \\
\hline $7 \mathrm{HP}$ & 0.257 & 0.259 & 0.264 & 0.267 & 0.271 & 0.275 & 0.278 \\
\hline 9HP & 0.360 & 0.365 & 0.369 & 0.374 & 0.379 & 0.384 & 0.389 \\
\hline
\end{tabular}

TableNo-4 
INTERNATIONAL JOURNAL OF INNOVATIVE RESEARCH IN ELECTRICAL, ELECTRONICS, INSTRUMENTATION AND CONTROL ENGINEERING Vol. 3, Issue 4, April 2015

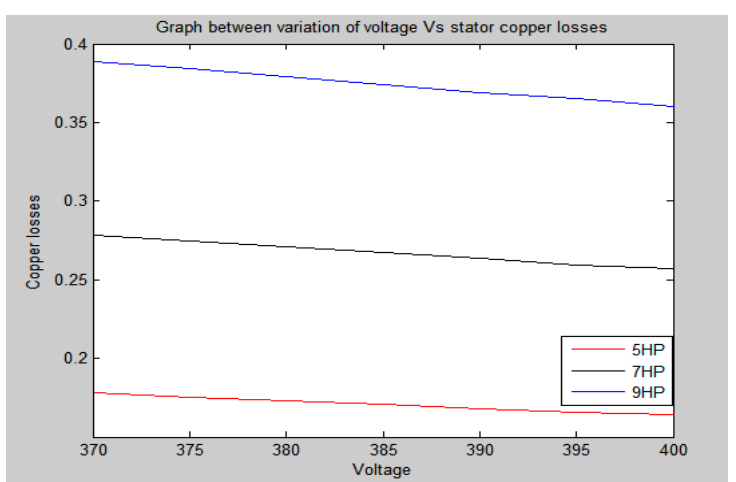

Graph No-3
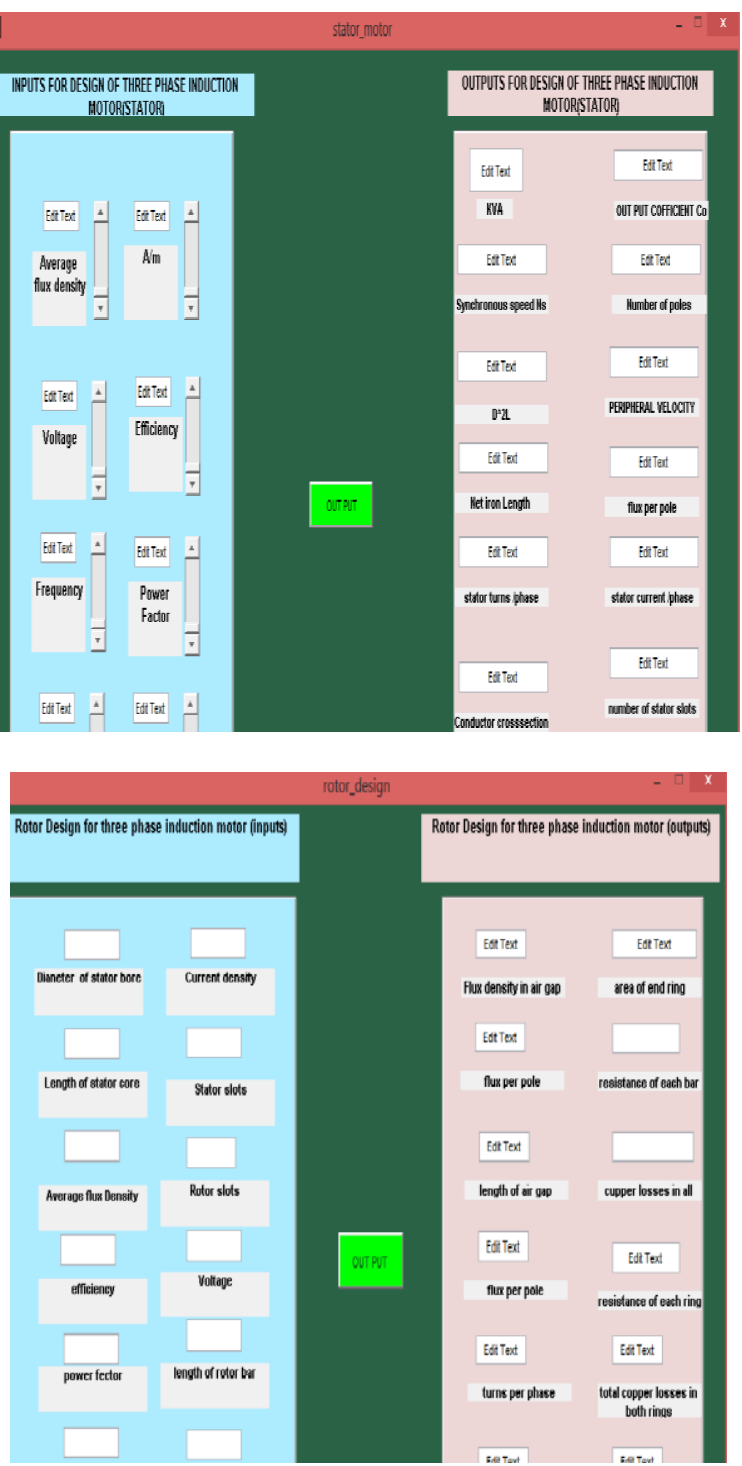

MATLAB-GUI for stator and Rotor Table No -5

\section{CONCLUSION}

The MATLAB-GUI results of three phase induction motor slightly varies in values when compared with the analytical results, the difference may occur due to the fact that the analytical calculations are full of approximations, time consuming and hence associated with frequent errors, but the slight difference between the analytical and the computer added values have not much effects on the design of the motor. The computer added design is much better as compared to the analytical calculations as it saves the time and the results will be more accurate. With the computer added design the effects of variations of parameters on the design can also be observed easily.

\section{REFERENCES}

[1] A.K.SAWHNEY, "A Course in Electrical Machine design", Dhanpatrai \& Sons.

[2] Sunil Sehra, "performance evaluation of three phase induction motor based on no load and blocked rotor test using mat lab 'International Journal of Science, Environment and Technology, Vol. 1, No 5, $2012,541-547$.

[3] A.K. Sawhney, Dr.A.Chakrabarti "A course in Electrical Machine Design", Dhanpat Rai \&Co (p) ltd, sixth edition, 2006.

[4] Deepa Vincent, "Bindu R, Three Phase Induction Motor Design in Windows Programming Platform', International Journal of Engineering and Innovative Technology (IJEIT) Volume 3, Issue 1, July 2013.

[5] Aanchal Baranwal, "Designing of Three Phase Induction Motor Using MATLAB GUI', MIT International Journal of Electrical and Instrumentation Engineering, Vol. 4, No. 1, January 2014, pp. 42-44 42ISSN 2230-7656 (C) MIT Publications.

[6] Dr.A.Raghuram, V. Shashikala, "Design and Optimization of Three Phase Induction Motor using Genetic Algorithm', International Journal of AdvancesComputerScienceanTechnology Volume2 No.6, June2013

[7] Ran N.Patel, "Programming in MATLAB'’Pearson. 